グルホシネート・フルミオキサジン顆粒水和郕の非選択性除草用 としての特性

第 2 報 固場条件下での殺草活性とその特長 松本啓志、○森田耕一、木沢悟（住友化学工業）

グルホシネート・フルミオキサジン顆粒水和剤（S-878 顆粒水和剂）の特性に ついては、その 1 部を前報で報告したが、本報では娄場条件下での効果およびその特 長について報告する。

\title{
1. 材料および方法
}

(1)固場条件下での除草活性住友化学工業試験農場（兵庫県加西市）の非農耕地お よび果樹園等に自生する 20 科 41 種の雑草に対するS - 878 顆粒水和剤の茎葉処 理での除草効果を調べた。試験は、春期から夏期にかけて複数回行った。いずれも、 処理量は $50 \mathrm{~g} / \mathrm{a}$ 、散布水量は $10 \mathrm{~L} / \mathrm{a}$ 、展着剤は無添加とした。除草効果は、処 理 14 日後の目視評価の結果を 0 （無効）〜 1000 （完全防除）の数值で表した。

(2)種々の時期における除草効果

早春処理での効果 3 月に、樹園地のヤエムグラ、ホトケノザおよびカラスノエン ドウ等にS -878 顆粒水和剤および比較都を茎葉処理した。

春期処理での効果 5 月に、樹園地のツユクサ、セイタカアワダチソウおよびナガハ ギシギシにS - 8 78 顆粒水和剂および比較剤を茎葉処理した。

夏期処理での効果 6 月に、樹園地のコヒルカオおよびイヌカラシ等に S -878 顆粒水和剂および比較剂を茎葉処理した。

各試験とも、散布水量は $10 \mathrm{~L} / \mathrm{a}$ 、展着剤は無添加、除草効果は目視評価とした。 (3)後次発生の雑草に対する効果阬リカフウロおよびイヌカラシ等の自生する非 農耕地にS - 8 78 顆粒水和剤および比較剤を処理した。処理 50 日後に試験区に発 生していた雑草の被度を草種ごとに目視調査した。

\section{2. 試験結果および考察}

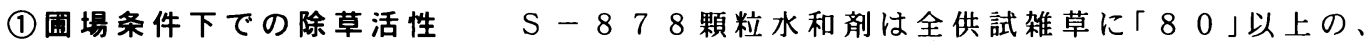
大部分の雑草に「９０」以上の効果を示し、本剤の殺草スペクトルの広さが示された。 特に広葉雑草に対する効果が安定していた。また、本剤の殺草症状は、高温期（夏期） では処理翌日に、低温期（春期）でも処理 3 日以内に発現していた（第 1 表）。

(2) 時期別の除草効果 $\quad S-878$ 顆粒水和剤は、早春、春期および夏期のいずれの 時期に処理されても優れた除草効果を示した (第 $2 \sim 4$ 表)。特に比較剤の効果が不安 定な早春処理でもS -878 顆粒水和剂の除草効果は安定していた（第 2 表）。

(3)後次発生の雑草に対する効果 $S-878$ 顆粒水和剤は処理時の既発生雑草に高 い効果を示すと共にメヒシバおよびアオビユ等の後次発生を抑止した（第 4 表）。

以上のように、S - 878 顆粒水和剤は固場条件下でも広範な雑草に有効であり早 春処理での効果も安定していた。更に雑草の後次発生を抑止する可能性も示された。 このように、本剤は既存剂とは異なる特性を围場条件下でも発揮しており非選択性除 草剤として有用性に富んだ剤と思われる。

Matsumoto、H., S.Kizawa and K.Morita:Herbicidal properties of water dispersible granule of Glufosinate-Flumioxazin mixture as a non selective herbicide.

2. Characteristic performance of the mixture under field conditions. 
第1表圈場試倹での除草効果の例

\begin{tabular}{|c|c|c|c|c|c|}
\hline$\overline{\text { 科 }}$ & 雜草名 & $\begin{array}{l}\text { 除草 } \\
\text { 効果 }\end{array}$ & $\begin{array}{l}\text { 效果発 } \\
\text { 現日数 }\end{array}$ & 処沿理日 & 量桑楅件 \\
\hline キク科 & ア刈カセンダングサ & 100 & 1 & 7.14 & 草丈 $15 \sim 30 \mathrm{~cm}$ \\
\hline & オオアレチルギク & 100 & 1 & 7.14 & 草丈 $10 \sim 30 \mathrm{~cm}$ \\
\hline & オナモミ & 93 & 1 & 8.06 & 草丈50cm \\
\hline & ヒメジョオン & 100 & 1 & 7.14 & 草丈5 20cm \\
\hline & セイタカアワダチッウ & 95 & 1 & 7.20 & 草丈35cm \\
\hline & セ体ウタンポ & 100 & 3 & 4.25 & 草丈20cm \\
\hline & 劢サブロ & 99 & 1 & 7.28 & 草丈 $45 \sim 50 \mathrm{~cm}$ \\
\hline & ノゲ & 100 & 1 & 7.17 & 草丈 $80 \sim 85 \mathrm{~cm}$ \\
\hline & ハホロギク & 96 & 2 & 5.27 & 開花期 \\
\hline & プタクサ & 100 & 1 & 7.14 & 8葉期 \\
\hline & $\exists E \neq^{\circ}$ & 93 & 1. & ...14 & 草丈 $10 \sim 30 \mathrm{~cm}$ \\
\hline アカネ科 & ヤI & 93 & 3 & 4.14 & $3 \sim 4$ 枝. \\
\hline さママ八グサ科 & オオイスノプ & 100 & 3 & 3.30 & 闗花期 \\
\hline ナス科 & イヌ杖ズキ & 100 & 1 & 6.01 & 5亲期 \\
\hline & チョウセンアサガオ & 100 & 1 & 6.01 & 8葉期 \\
\hline シソ科 & 朴ヶ等 & 100 & 3 & 4.14 & 闗花期 \\
\hline ヒルガオ科 & ב내ガ & 95 & 1. & 6.30 & 10篮以上. \\
\hline アオイ科 & 华 & 100 & 1. & ..24.......... & 草丈 $40 \sim 60 \mathrm{~cm}$ \\
\hline 力夕バ科 & 荈多三 & 90 & 3. & 4.21 & 墙殖䳢. \\
\hline 7吹蟀. & 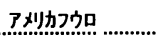 & 100 & 2. & 4.16 & 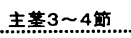 \\
\hline マメ科 & カラスハルドウ & 98 & 2 & 4.14 & 草丈 $30 \sim 40 \mathrm{~cm}$ \\
\hline & シロツメクサ & 100 & 1 & 7.14 & 開花期 \\
\hline
\end{tabular}

\begin{tabular}{|c|c|c|c|c|c|}
\hline 科 & 雜草名 & 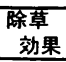 & $\begin{array}{l}\text { 効果発 } \\
\text { 現日数 }\end{array}$ & $\begin{array}{r}\text { 媪 } \\
\text { 拠理白 } \\
\end{array}$ & 理条件 \\
\hline アブラナ科 & $\begin{array}{l}\text { イスガラ } \\
\text { tズt }\end{array}$ & $\begin{array}{r}98 \\
100\end{array}$ & $\begin{array}{l}1 \\
3 \\
.\end{array}$ & $\begin{array}{l}6.30 \\
4.12\end{array}$ & $\begin{array}{l}\text { 開花期 } \\
\text { 草丈 } 55 \mathrm{~cm} .\end{array}$ \\
\hline ナデシコ科 & $\begin{array}{l}\text { オランダミミナグサ } \\
\text { ハコベ } \\
\text { !ミノスス }\end{array}$ & $\begin{array}{l}100 \\
100 \\
100\end{array}$ & $\begin{array}{l}2 \\
1 \\
3\end{array}$ & $\begin{array}{l}4.21 \\
6.01 \\
3.05 \\
. .0\end{array}$ & $\begin{array}{l}\text { 開花期 } \\
\text { 開花期 } \\
3 \sim 4 \text { 分技. }\end{array}$ \\
\hline 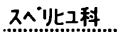 & 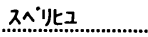 & 95 & 1. & 8.28 & $6 \sim 7$ 蕃期 \\
\hline 늑… & ?tūn & 98 & 1. & .7 .24 & 草丈35 55cm \\
\hline アカザ科 & ing* & 93. & 1. & 7.17 & 草丈 $55 \sim 60 \mathrm{~cm}$ \\
\hline タデ科 & $\begin{array}{l}\text { ハルダ } \\
\text { エソ゚リギシギシ. }\end{array}$ & $\begin{array}{c}100 \\
90 \\
9 . . . .\end{array}$ & $\begin{array}{l}2 \\
3\end{array}$ & $\begin{array}{l}5.27 \\
3.10 \\
\ldots . .1 .\end{array}$ & $\begin{array}{l}\text { 閒花期 } \\
15 \mathrm{~cm}, 10 \text { 蕉期. }\end{array}$ \\
\hline ℶク年科 & 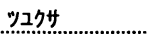 & 100 & 1. & 6.20 & 冓花期䛔焦 \\
\hline カヤッツグサ科 & | & 95 & 1. & ...28. & 草丈50 60 \\
\hline イネ科 & 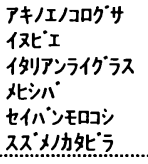 & $\begin{array}{c}100 \\
95 \\
90 \\
90 \\
93 \\
85\end{array}$ & $\begin{array}{l}1 \\
1 \\
3 \\
1 \\
3 \\
3\end{array}$ & $\begin{array}{c}6.20 \\
8.06 \\
4.16 \\
6.3 \\
5.25 \\
4.21 \\
.1 .\end{array}$ & 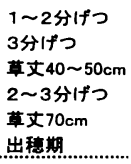 \\
\hline トクサ科 & ㅈギナ & 85 & 1 & 6.20 & $9 \sim 10$ 節 \\
\hline
\end{tabular}

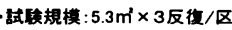

奶理: 3月30日

処理時の雓草の大きさ

ヤエムグラ…草丈 $20 \mathrm{~cm}$

朴ヶルサ、オオ仅フグリ・...閐花期

カラスハントウ・草丈 $30 \sim 40 \mathrm{~cm}$

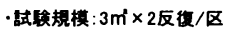
-処理:5月30日

·処理時の雓草の大きさ

ッユクサ…草丈15～25cm セ仍アワダチリウ…同40～60cm 职ギシギシ・葉柃る〜4莱

\begin{tabular}{|c|c|c|c|c|c|c|}
\hline \multirow{3}{*}{$\frac{\text { 第4表 }}{\text { 供試剂 }}$} & \multicolumn{6}{|c|}{ 夏期処理での除草効果 } \\
\hline & \multirow{2}{*}{$\begin{array}{c}\text { 処理量 } \\
(\mathrm{g}, \mathrm{ml} / \mathrm{a})\end{array}$} & \multirow{2}{*}{$\begin{array}{c}\text { 既察日 } \\
\text { (処理後日数) }\end{array}$} & \multicolumn{2}{|r|}{ 襍 } & \multicolumn{2}{|c|}{ 草 } \\
\hline & & & コヒルガオ & 㑃ラシ & アオピュ & 多サプ \\
\hline $\begin{array}{l}S-878 \text { 顆粒 } \\
\text { 水和剂 }\end{array}$ & 50 & $\begin{array}{r}5 \\
11\end{array}$ & $\begin{array}{l}95 \\
96 \\
\end{array}$ & $\begin{array}{l}78 \\
98\end{array}$ & $\begin{array}{l}95 \\
99\end{array}$ & $\begin{array}{r}95 \\
100\end{array}$ \\
\hline $\begin{array}{l}\text { グルホシネート } \\
\text { 18.5\%液剤 }\end{array}$ & 50 & $\begin{array}{r}5 \\
11 \\
\end{array}$ & $\begin{array}{l}83 \\
91\end{array}$ & $\begin{array}{l}58 \\
92 \\
\end{array}$ & $\begin{array}{l}88 \\
95 \\
\end{array}$ & $\begin{array}{r}95 \\
100 \\
\end{array}$ \\
\hline
\end{tabular}

- 弑駼规模 : $9.4 \mathrm{~m}^{2} \times 2$ 反復/区

.処理:6月30日

・処理時の雑草の大きさ

コヒルガオ $\cdots$ 旬甸茎畏 $30 \mathrm{~cm}$ その他蒦草…草丈15 18cm

第5表処理50日後の雑草発生量(植被率)

\begin{tabular}{|c|c|c|c|c|c|c|}
\hline \multirow[t]{2}{*}{ 供 試 剂 } & \multirow{2}{*}{$\begin{array}{c}\text { 処理量 } \\
(\mathrm{f} . \mathrm{g}, \mathrm{ml} / \mathrm{a})\end{array}$} & \multirow{2}{*}{ 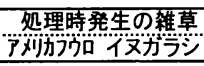 } & \multicolumn{3}{|c|}{ 処理後無生の雓草 } & \multirow[b]{2}{*}{ 杜深 } \\
\hline & & & 站济" & 罗15 & 附五 & \\
\hline S-878顆粒水和敖 & 50 & \pm & \pm & \pm & - & ....... \\
\hline クルホシネート18.5\%液用 & 50 & \pm & +++ & \pm & \pm & \pm \\
\hline
\end{tabular}

